\title{
Current status of breast implant survival properties and the management of the woman with silicone gel breast implants
}

\author{
Walter Peters PhD MD FRCSC
}

\section{W Peters. Current status of breast implant survival properties and the management of the woman with silicone gel breast implants. Can J Plast Surg 2000;8(2):54-67.}

The survival properties of silicone gel breast implants are dependent on their vintage (year of manufacture), duration in situ and manufacturer. A total of 527 gel implants have been explanted and analyzed in the author's laboratories. Of the 28 first-generation implants (1963 to 1972), 27 (96.4\%) remained intact after 14 to 28 years in situ (mean 20.8 years). Of the 216 second-generation implants (1973 to mid-1980s) that were explanted from 1992 to 1998, 158 (73\%) had disrupted. Kaplan-Meier survival curves demonstrated significantly different survival properties among second-generation manufacturers. Surgitek implants were by far the least durable. After 14 years, all second-generation Surgitek implants had disrupted. By contrast, after 20 years, about half of the Dow Corning and Heyer-Schulte implants remained intact. Among third-generation implants (mid-1980s to 1992), 43 of 46 (93.4\%) remained intact after a mean of 6.3 years (range three to 12 years). The three disruptions were Surgitek implants. Implants from other manufacturers remained intact. However, the disruption frequencies of third-generation implants have yet to be measured over the relevant periods of time. Survival patterns appeared to be related to the thickness of the elastomeric shell of the three generations of implants. Mechanical strength analyses of the elastomeric shells of explants have exhibited little or no large scale material degradation, even after as long as 28 years in situ. The mechanism of implant disruption likely involves the 'fold flaw' theory, whereby an internal abrasion can develop over time at the site of a fold in the implant wall. Diagnosis of disruption is difficult. Mammography is helpful only if there has been extravasation of silicone gel into breast tissue. Extravasation was observed in only 4.2\% of second-generation implants removed from 1992 to 1998. It was not seen with first- or third-generation implants. Ultrasound analyses are not generally helpful to predict disruption because they are very operator dependent and because capsular contracture causes folds in the implant wall, which result in false positives. Magnetic resonance imaging is the most accurate imaging modality to detect implant disruption. However, this technology is not indicated for monitoring implant status because it is too costly and time consuming, and because it has significant limitations, particularly with first-generation and textured implants. Careful explantation and direct visual examination are the standards for diagnosing gel implant disruption. Many implant disruptions are likely 'silent', with no specific symptoms or clinical findings. After disruption, none of the following are elevated above the levels seen in control women without implant exposure: serum autoantibodies, blood and serum silicon, and the incidence of breast cancer, autoimmune disease or any other medical disease. There is no evidence to support the existence of any 'novel' or 'atypical' syndrome associated with gel implants. Women over 30 years of age with breast implants require regular monitoring for breast cancer detection. This should include monthly breast self examination and annual clinical breast examination. In addition, women over 50 years old require annual eight-view mammographic assessment using the implant displacement technique. Even then, breast implants have been shown to interfere with complete imaging, particularly if the implants are subglandular, large or associated with significant capsular contracture. A logical approach to explantation should involve consideration of a patient's personal concerns and anxiety, her implant vintage, the plane of insertion of her implants, her current clinical status and whether she chooses to replace her gel implants. Women requesting explantation require extensive information before deciding on surgery. At explantation, capsulectomy seems to be indicated if there is capsular calcification or major capsular thickening. (Pour le résumé, voir page suivante)

Key Words: Breast implants; Breast implant disruption; Silicone gel 


\section{État actuel des propriétés de durée de vie des prothèses mammaires et traitement des femmes porteuses de prothèses mammaires de silicone}

RÉSUMÉ : Les propriétés de durée de vie des prothèses mammaires de silicone dépendent de l'année de fabrication, de la durée de mise en place et du fabricant. Un total de 527 prothèses de silicone ont été extraites et analysées aux laboratoires de l'auteur. Des 28 prothèses de la première génération (de 1963 à 1972), 27 (96,4\%) d'entre elles étaient intactes après une durée de mise en place de 14 à 28 ans (20,8 ans en moyenne). Des 216 prothèses de la deuxième génération (de 1973 au milieu des années 80) extraites entre 1992 et 1998, 158 (73\%) d'entre elles présentaient une rupture. Les courbes de durée de vie selon la méthode de Kaplan-Meyer ont montré des différences significatives, entre les fabricants, quant aux propriétés de durée de vie des prothèses de la deuxième génération. Les prothèses Surgitek étaient de loin les moins durables. Après 14 ans, toutes les prothèses Surgitek de la deuxième génération présentaient une rupture. À l'opposé, environ la moitié des prothèses Dow Corning et Heyer-Schulte étaient intactes après 20 ans. Parmi les prothèses de la troisième génération (du milieu des années 80 à 1992 ), 43 prothèses sur 46 $(93,4 \%)$ étaient intactes après une durée de vie moyenne de 6,3 ans (entre trois et douze ans). Les trois qui présentaient une rupture étaient des prothèses Surgitek. Les prothèses des autres fabricants étaient intactes. Toutefois, la fréquence de rupture des prothèses de la troisième génération reste à évaluer sur une période de temps appropriée. Les propriétés de durée de vie semblent liées à l'épaisseur de l'enveloppe d'élastomère des prothèses de la troisième génération. Les analyses de résistance mécanique de l'enveloppe d'élastomère des explants ont révélé peu ou pas de dégradation matérielle à grande échelle, même après une durée de mise en place de 28 ans. Le mécanisme de rupture des prothèses s'explique sans doute par la théorie du faux pli selon laquelle une abrasion interne risque de s'installer avec le temps à l'endroit du pli dans la paroi de la prothèse. Les ruptures sont difficiles à diagnostiquer. La mammographie ne peut les détecter que s'il y a eu épanchement de silicone dans les tissus mammaires. On a observé un épanchement chez seulement 4,2\% des femmes porteuses de prothèses de la deuxième génération, extraites entre 1992 et 1998. Tel n'était pas le cas avec les prothèses de la première et de la troisième génération. Les échographies ne sont habituellement pas utiles pour prévoir les ruptures parce que leur efficacité repose beaucoup sur l'habileté du technicien et parce que la contracture capsulaire entraîne des plis dans la paroi de la prothèse, ce qui se traduit par des résultats faux positifs. L'imagerie par résonance magnétique est l'examen le plus précis pour déceler les ruptures de prothèse. Cependant, elle n'est pas indiquée pour contrôler l'état de la prothèse parce qu'elle coûte trop cher et prend beaucoup de temps. De plus, elle présente d'importantes limites, surtout en ce qui concerne les prothèses de la première génération et les prothèses texturées. Une extraction soigneuse des prothèses et un examen visuel direct sont la norme pour diagnostiquer les ruptures de prothèse de silicone. Un grand nombre de ruptures de prothèse sont « asymptomatiques », c'est-à-dire non accompagnées de symptômes précis ou de signes cliniques. Comparativement aux femmes témoins n'ayant pas porté de prothèses, les femmes dont les prothèses présentaient une rupture n'avaient pas plus d'anticorps sériques, de silicone dans le sang et le sérum, d'incidence du cancer du sein, de maladie auto-immune ou de tout autre type de maladie. Rien n'étaye l'existence de quelque syndrome «nouveau » ou « atypique » associé aux prothèses de silicone. Les femmes âgées de plus de 30 ans, porteuses de prothèses mammaires doivent subir des examens réguliers de dépistage du cancer du sein, dont l'auto-examen mensuel et un examen clinique annuel des seins. En outre, les femmes âgées de plus de 50 ans doivent subir une mammographie annuelle à huit incidences à l'aide de la technique de déplacement des prothèses. Même là, on a déjà vu des prothèses mammaires brouiller la formation des images, surtout si elles sont sous-glandulaires, grosses ou associées à une contracture capsulaire importante. Une approche logique à l'égard de l'extraction devrait tenir compte des préoccupations personnelles et de l'anxiété de la patiente, de l'année de mise en place des prothèses, de leur plan d'insertion, de l'état clinique actuel de la femme et de sa décision quant au remplacement des prothèses de silicone. Avant d'opter pour la chirurgie, les femmes demandent beaucoup de renseignements. À l'extraction, une capsulectomie semble indiquée en cas de calcification capsulaire ou d'épaississement capsulaire important.

\section{SILICONE GEL BREAST IMPLANTS}

Silicone gel breast implants were introduced in 1963 by Cronin and Gerow (1) as new 'natural feel' implants. They consist of a rubber-like silicone elastomer envelope (shell), which varies in thickness from 0.075 to $0.75 \mathrm{~mm}(0.003$ to 0.030 inches), enclosing a known volume of silicone gel (2), ranging from 80 to $800 \mathrm{~cm}^{3}$. The elastomer is composed of extensively cross-linked high molecular weight components, together with $16.4 \%$ to $26.9 \%$ amorphous fumed silica filler, which is used as a reinforcing agent. The mechanical properties of silicone elastomer are relatively weak. Silica increases this mechanical strength up to 40 -fold. The gel consists of a mixture of low molecular weight (6000 to $38,000 \mathrm{Da})$ and high molecular weight (up to 404,000 Da) components (2). Solvent extraction of the envelope and of the gel has revealed 30 different linear and cyclic components (2).

\section{PREVALENCE}

Silicone gel breast prostheses were originally implanted in small numbers, and these numbers slowly increased. From 1962 to 1970 , only about 50,000 women received gel im- plants in the United States (3). Subsequently, the number of women receiving implants rose annually. In 1982, about 100,000 women received implants (3). From 1983 to 1991, this number remained constant at 120,000 to 130,000 per year. Estimates indicate that, by $1988,1.0$ to 1.27 million women had received breast implants and that over $95 \%$ were gel-filled (3). In 1989, the prevalence of silicone gel breast implants among women in the United States over 18 years of age was estimated to be about $1 \%(3,4)$.

\section{First-generation implants}

\section{IMPLANT VINTAGE}

There have been three main generations of silicone gel breast implants (5-7). First-generation implants were made from about 1963 to 1972. During this time, Dow Corning had an almost exclusive monopoly on their manufacture. The implants were composed of a thick (firm) gel and a thick elastomeric wall (Figures 1,2). From 1963 to 1968, the shells were $0.75 \mathrm{~mm}$ thick (Figure 1). They were prepared by peroxidebased technology using a molding technique to produce a preformed seamed shell, which was subsequently filled with 


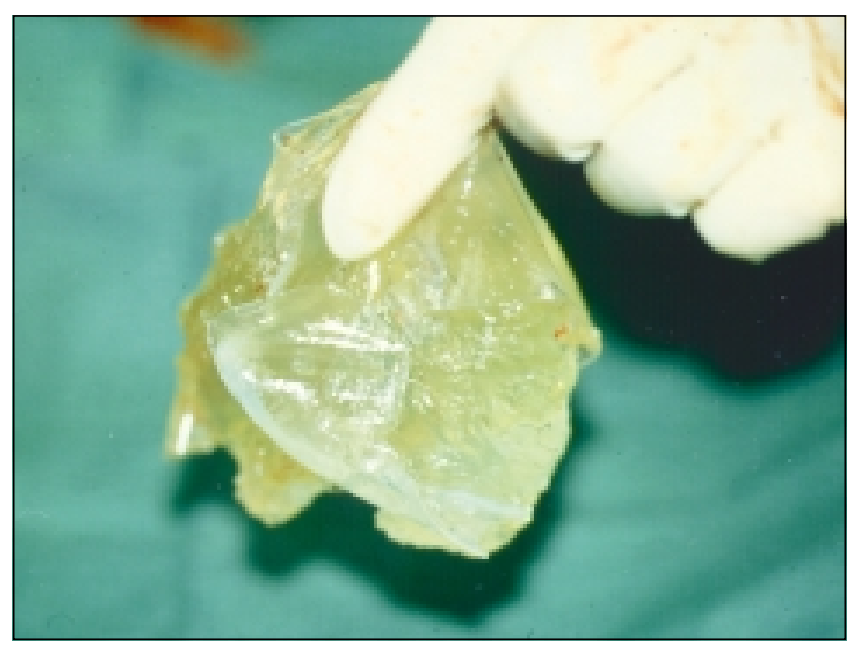

Figure 1) First-generation gel implant (Dow Corning, Cronin, seamed, 1967) composed of a thick (firm) gel and a thick elastomeric wall $(0.75 \mathrm{~mm})$. The implant has been opened along its circumference with a scalpel to show that the gel is very cohesive

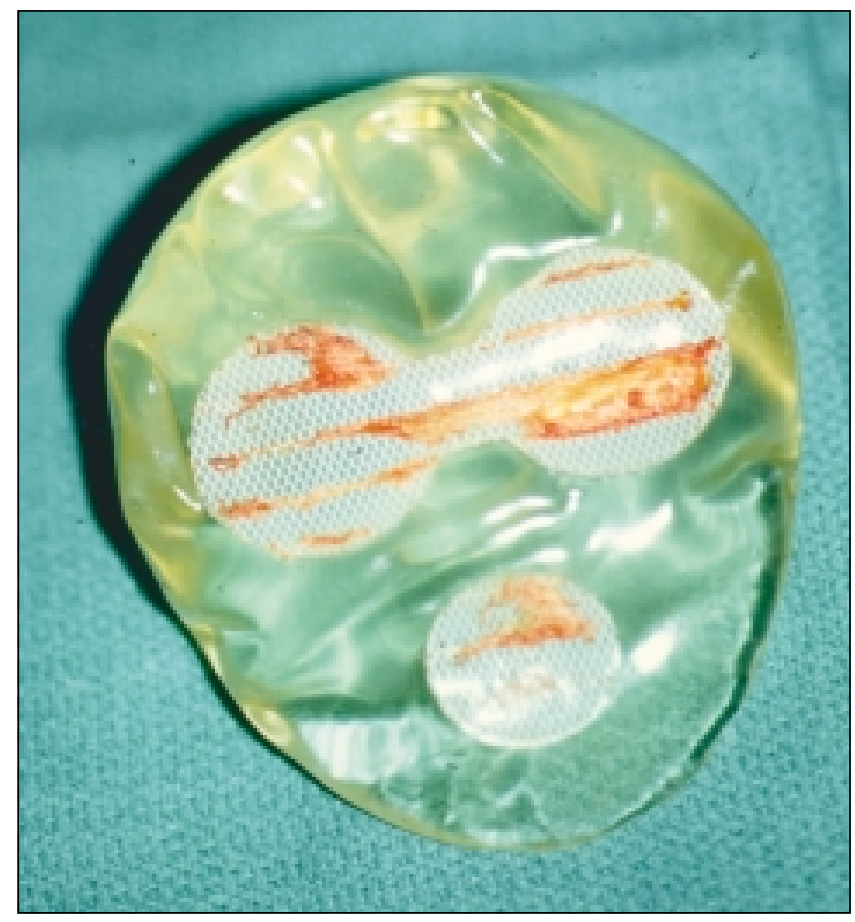

Figure 2) First-generation implant (Dow Corning, seamless, Silastic 0 , 1971) with two Dacron patches on the posterior surface, one in the shape of a dumbbell. First-generation implants have proved to be stronger and more durable than second-generation implants

gel. From 1969 onwards, platinum-based technology was used, and all shells were seamless (the Silastic 0 implant, Figure 2). These shells were produced by automated 'dipcoating' a form (mandrel) into an elastomeric dispersion. The shell was then removed from the mandrel, gel was injected into it and the injection perforation site was sealed with adhesive silicone. These shells were about $0.25 \mathrm{~mm}$ thick.

First-generation implants had woven dacron patches on
TABLE 1

Thickness of elastomeric shells for the three generations of silicone gel implants

\begin{tabular}{ll}
\hline Generation & Shell thickness $(\mathbf{m m})$ \\
\hline First & \\
1963 to 1968 & 0.75 \\
1969 to 1972 & 0.25 \\
Second & 0.13 \\
Third & 0.50 \\
\hline
\end{tabular}

their posterior surface to anchor them to the chest wall, in an attempt to reduce ptosis. Implants made in 1963 had a single patch that covered the entire posterior implant wall (the 'Cronin seamed prosthesis'). Only four implant sizes were available. In 1964, this patch was replaced with fourquadrant patches. In 1968, this configuration was changed to three, four or five patches (Figure 2), depending on the implant volume. One of these patches was usually dumbbell shaped (Figure 2). First-generation implants have proved to be much stronger than those developed subsequently $(8,9)$, likely due to the thickness of their elastomeric shell (Table 1).

Many women who received first-generation implants developed very firm breasts, often within a year of their surgery. This was due to capsular contracture, a process that was not well understood at the time. It was surmised that this firmness was due to the firmness of the implants. Softer (second-generation) implants were, therefore, developed with the hope that they may result in softer breasts.

\section{Second-generation implants}

Second-generation implants had a thin gel and a thin wall $(0.13 \mathrm{~mm})$ (Table 1, Figure 3). The thickness or firmness of the gel was related to the relative amount of highly crosslinked material in the gel. The thick or firm gel contained about $50 \%$ highly cross-linked silicone and about 50\% low molecular weight chains. By contrast, the thin or 'responsive' gel contained only about $20 \%$ highly cross-linked silicone and $80 \%$ low molecular weight chains. The gel is much less viscous (Figure 3 ) than that of first-generation implants (Figure 2). Many second-generation implants have become disrupted over time $(8,9)$.

Each manufacturer released its product during different years, and each implant model was usually introduced earlier in the United States than in Canada (Table 2). Heyer-Schulte released the first soft ('cohesive') gel implant in the United States in 1972 and in Canada in 1974. Medical Engineering Corporation/Surgitek introduced a similar product in the United States in 1972, but it was not released in Canada until 1979. Dow Corning introduced a comparable product (the 'responsive gel', Silastic I implant) in the United States in 1975 and in Canada in 1978 (Table 2). Fixation patches were discontinued on most implants by 1975 . They were available on selected models through 1984, and subsequently only by special order. Many of the patches on second-generation implants were composed of silicone alone rather than silicone 


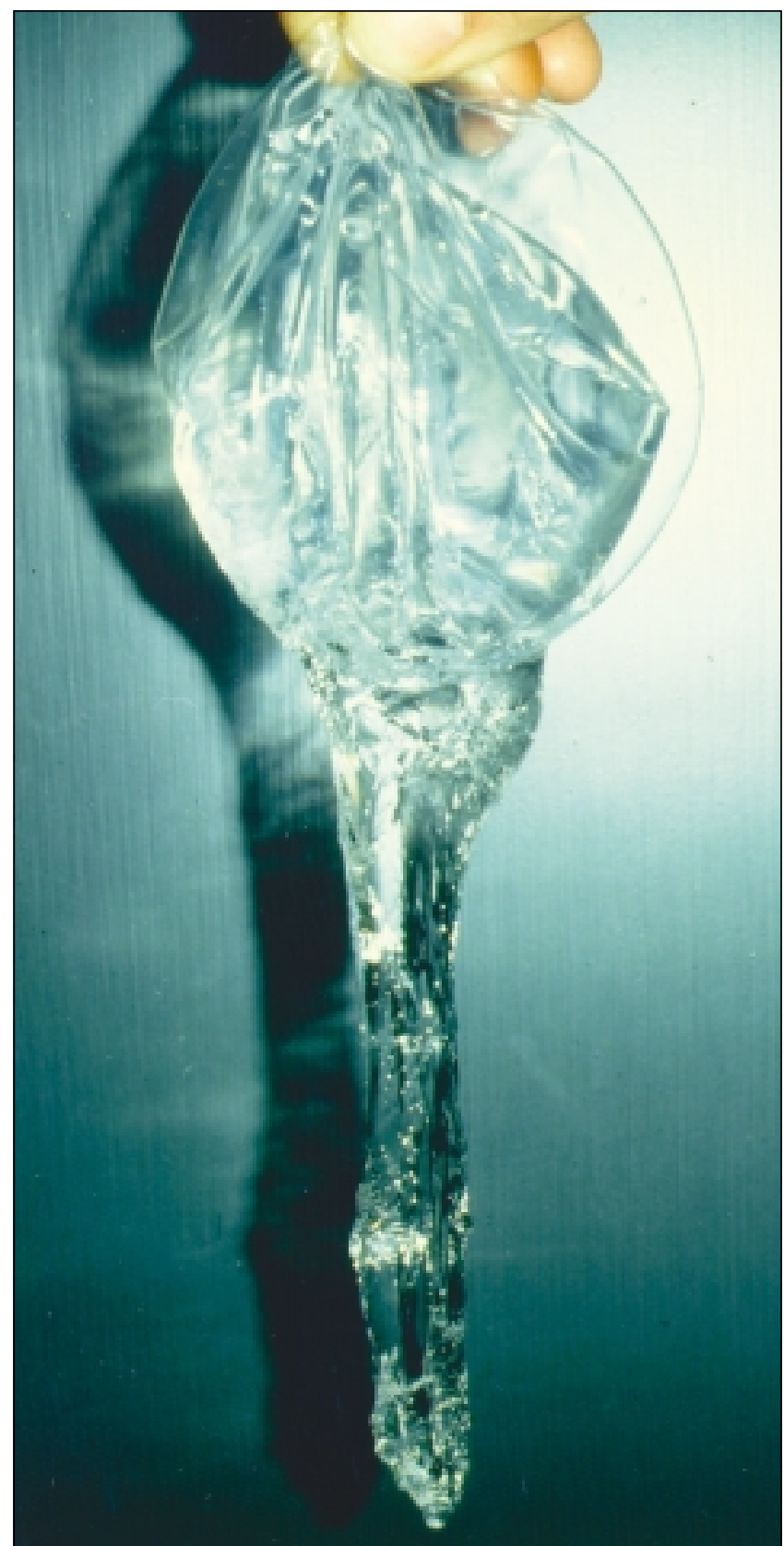

Figure 3) Second-generation implant with a thin, 'responsive' (noncohesive) gel and a thin wall $(0.13 \mathrm{~mm})$. The gel is much less viscous and less cohesive than that of first-generation implants. Many of these implants have become disrupted over time

with dacron. They provided less fixation than dacron patches.

Surgeons soon noticed that many patients with secondgeneration implants also developed firm breasts, in spite of the 'soft' nature of the implants. When these patients underwent open capsulotomy, a number of these implants were found to be disrupted. Manufacturers added disclaimers to their product inserts, stating that "currently available mammary prostheses are not perfect - the elastomer has a low tear strength and is thin to achieve softness". Manufacturers initially endorsed the autoclaving of silicone gel implants. Sub-
TABLE 2

Introduction of second-generation silicone gel implants in the United States and Canada

\begin{tabular}{lcc}
\hline & \multicolumn{2}{c}{ Year of introduction } \\
Manufacturer & United States & Canada \\
\hline Heyer-Schulte & 1972 & 1974 \\
Surgitek & 1972 & 1979 \\
Dow Corning & 1975 & 1978 \\
\hline
\end{tabular}

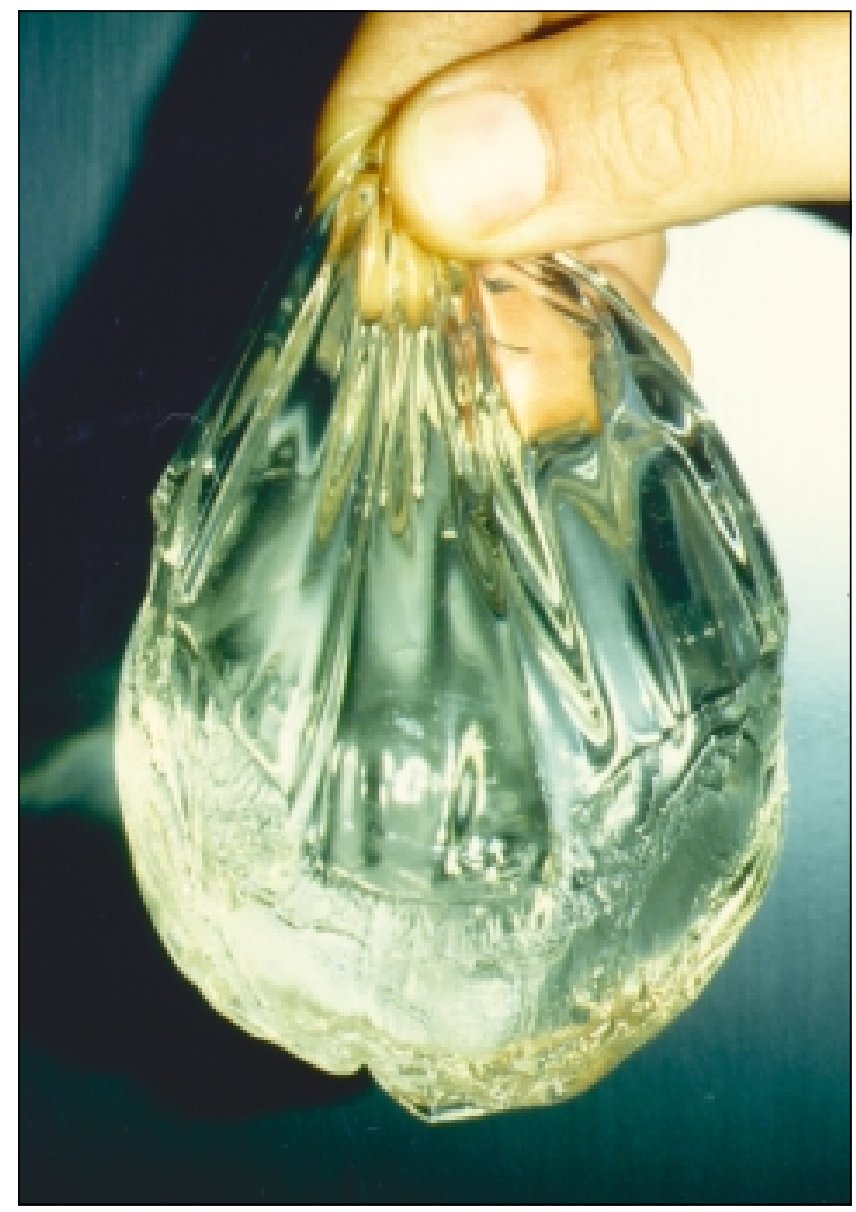

Figure 4) Third-generation implants had a stronger and thicker $(0.50 \mathrm{~mm})$ shell, and a much more cohesive gel than second-generation implants. This implant has been opened along its lower border with a scalpel. The exposed gel is very cohesive compared with that of secondgeneration implants (see Figure 3)

sequently, when the walls of these implants were noted to tear easily (particularly if they were still hot), companies added a disclaimer against autoclaving. Manufacturers ultimately addressed the implant disruption problem by developing the third-generation implant.

\section{Third-generation implant}

The third-generation implant had a stronger and thicker $(0.50 \mathrm{~mm})$ shell (high performance) and a much more cohesive gel (Figure 4) than second-generation implants (Figure 3). They also had a 'barrier layer' to reduce the diffusion of sili- 
TABLE 3

Introduction of third-generation silicone gel implants in the United States and Canada

\begin{tabular}{lcc}
\hline & \multicolumn{2}{c}{ Year of introduction } \\
Manufacturer & United States & Canada \\
\hline McGhan (Intrashiel) & 1979 & 1980 \\
Dow Corning (Silastic II) & 1981 & 1984 \\
Surgitek (strong cohesive, low bleed) & 1986 & 1988 \\
\hline
\end{tabular}

cone, which was thought to increase capsular contracture. McGhan released the first third-generation implant - the Intrashiel - in the United States in 1979 (Table 3). It had a diphenyl barrier layer of proprietary composition, sandwiched between an inner and outer layer of high performance elastomer.

Other companies followed with similar types of implants. The third-generation Dow Corning implant (Silastic II) had a fluorosilicone layer to restrict silicone bleed. Half of the methyl groups on the polysiloxane chains were replaced with trifluoropropyl groups. This barrier layer was only 5 to $10 \mu \mathrm{m}$ thick and was located on the inner surface of the elastomeric shell. The corresponding Surgitek implant (strong cohesive, low bleed) had a barrier layer that was incorporated into the wall of the shell rather than on the surface. This layer was formed by diphenyl groups that were substituted for some of the dimethyl groups in the silicone elastomer. The introduction of third-generation implants was geographically dependent (Table 3). The Silastic II implant was introduced by Dow Corning in the United States in 1981 and in Canada in 1984. The Surgitek strong cohesive, low bleed implant was introduced in the United States in 1986 and in Canada in 1988 (Table 3).

\section{Other gel implants}

Over the years, more than 240 styles of silicone gel breast implants have been manufactured in the United States alone $(6,7)$. It has been further estimated that as many as 8300 different models of gel implants were available over the years $(6,7)$. There have been numerous manufacturers and designs of implants, including single-lumen, double-lumen, reverse double-lumen, triple-lumen, smooth, textured and adjustable implants, and implants with various contours. Of particular interest, two types of gel implants were intentionally manufactured without a shell $(6,7)$ : the Cavon implant and one style of the Aesthetech implant. Both implants were used in several areas of the United States from 1979 to 1986.

\section{SOURCE OF GELS AND ELASTOMERS}

Over the years, the exact source of the gels and elastomers for each manufacturer was quite variable $(6,10)$. Dow Corning always used their own gel and elastomer. Other manufacturers obtained their gels from a variety of sources. From 1972 to 1976 , most obtained gel from General Electric $(6,10)$. From 1976 to 1991, some manufacturers (including Aesthetech, Heyer-Schulte, Cox Uphoff and Medical Engineering

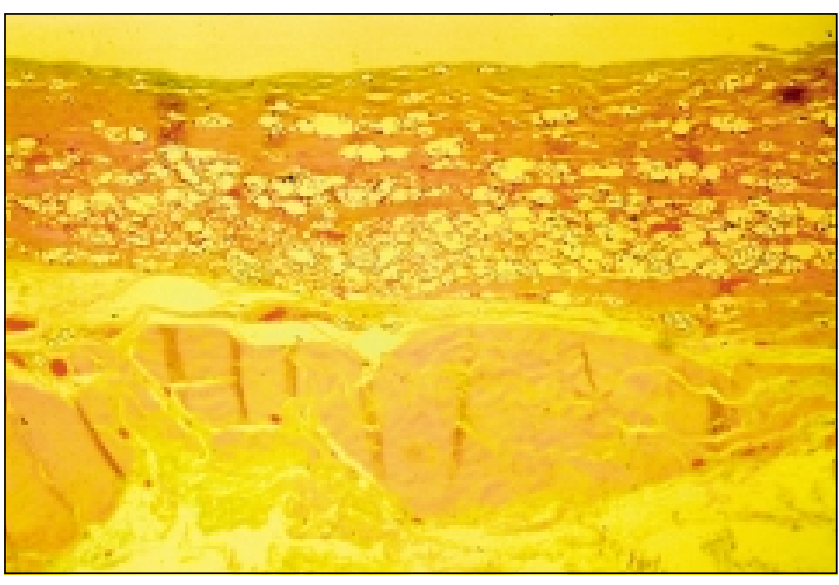

Figure 5) World Health Organization stain of the capsule surrounding a first-generation gel implant. The upper border of the capsule was adjacent to the implant. Although the implant had remained clinically intact 19 years after implantation, silicone has accumulated within the capsule after 'bleeding' through the elastomeric shell of the implant (magnification $\times 50$ )

Corporation-Surgitek) often obtained their gel and elastomeric raw materials (dispersion fluid to dip-coat the gel) from Dow Corning. However, from 1984 to 1992, many implant manufacturers also obtained gel and elastomeric raw materials from other companies, including Admiral Materials, Applied Silicone, Polymer Technologies and International Silicone Corporation. From 1977 to 1984, McGhan supplied its own gel (McGhan Nusil Corporation, which became a subsidiary of Union Carbide in 1990). The sourcevariability of gel and elastomeric raw materials likely contributed to the different mechanical properties of implants from different manufacturers.

\section{CHRONOLOGY OF THE MANUFACTURERS}

The chronology of the various implant manufacturers is confusing. Many of the companies underwent multiple name changes over the years. Litigation lawyers have had their hands full just keeping track of them (10). Heyer-Schulte began to manufacture gel implants in 1971. In 1974, they were acquired by American Hospital Supply. The Heyer-Schulte division of that company was acquired by Mentor in 1984. In 1985, American Hospital Supply Corporation was merged into Baxter Healthcare Corporation. Although Baxter never manufactured breast implants, they became legally responsible for many of the earlier Heyer-Schulte implants because of their acquisition of the American Hospital Supply Corporation.

McGhan initially manufactured gel implants in 1974 and merged into 3M in 1980. In 1984, McGhan acquired the company back from 3M. In 1985, that company was in turn acquired by First American and the name was changed to Inamed. Cox Uphoff began to manufacture gel implants in 1975. In 1989, the company was acquired by Inamed, and the name was changed to Cox Uphoff International, which went bankrupt in 1991. Medical Engineering Corporation/Surgitek began to manufacture gel implants in 1971. In 1982, the 
company was acquired by Bristol-Myers Squibb, who subsequently became legally responsible for many of the earlier implants.

\section{SILICONE BLEED}

Since 1978, it has been recognized that silicone can be expected to 'bleed', by diffusion, from all clinically intact gel implants (11). This phenomenon has been shown to increase under load (2) (eg, capsular contracture). Figure 5 shows a World Health Organization stain of the capsule surrounding a first-generation implant that was removed after 19 years in situ. Although the implant remained clinically intact, globules of silicone have accumulated within the capsule, after 'bleeding' through the intact elastomeric shell. Studies have now shown that the level of silicon in the capsules from intact first-generation gel implants is similar to the silicon levels of capsules from ruptured second-generation implants (12).

Several studies have attempted to measure the rate and composition of this silicone bleed (13 and unpublished data). Dow Corning analyzed gel bleed from Silastic I implants after applying a $5 \mathrm{~kg}$ weight for over 30 days (unpublished data). There was an average of $840 \mathrm{mg}$ of bleed per implant. About $97 \%$ consisted of a polymer with an average molecular weight of 23,630 Da, likely from the swelling fluid used in the manufacture of the implants. The other $3 \%$ consisted of a high molecular weight component (more than 200,000 Da) that appeared to originate from uncross-linked silicone in the shell (unpublished data). By contrast, when $5 \mathrm{~kg}$ were applied to Silastic II implants, only $45 \mathrm{mg}$ of bleed was obtained from each implant because of the barrier coat (unpublished data). About $77 \%$ was a low molecular weight component (from the swelling fluid), and $23 \%$ was a very high molecular weight component (from residual uncross-linked polymer in the shell) (unpublished data).

Callahan (2) and $\mathrm{Yu}$ et al (13) have attempted to measure the annual bleed rates of Silastic II implants into saline or simulated body fluids. The measured rates were $100 \mathrm{mg}$ and $220 \mathrm{mg}$ per year. Extrapolating to the in vivo situation is difficult because the ultimate rate of bleed is limited by the rate of diffusion through the shell and the rate of removal of the bleed from the exterior surface of the implant. This, in turn, would be limited by silicone solubility and by the presence of capsular tissue, which would provide an additional barrier to bleed.

There is some indication that, over the longer term, the barrier layer of some third-generation implants may not remain effective. Several studies have indicated that, over time, the capsule silicon levels of barrier-coated implants are not different from those of first-generation implants $(12,14-17)$. A bleed is not considered to represent disruption of a gel implant because all gel implants bleed with time.

\section{Definition of disruption}

\section{IMPLANT DISRUPTION}

Silicone gel fluid is regularly found on the surface of gelfilled implants. This represents 'bleed', not disruption. Disruption refers to the breakdown of the integrity of the elasto-

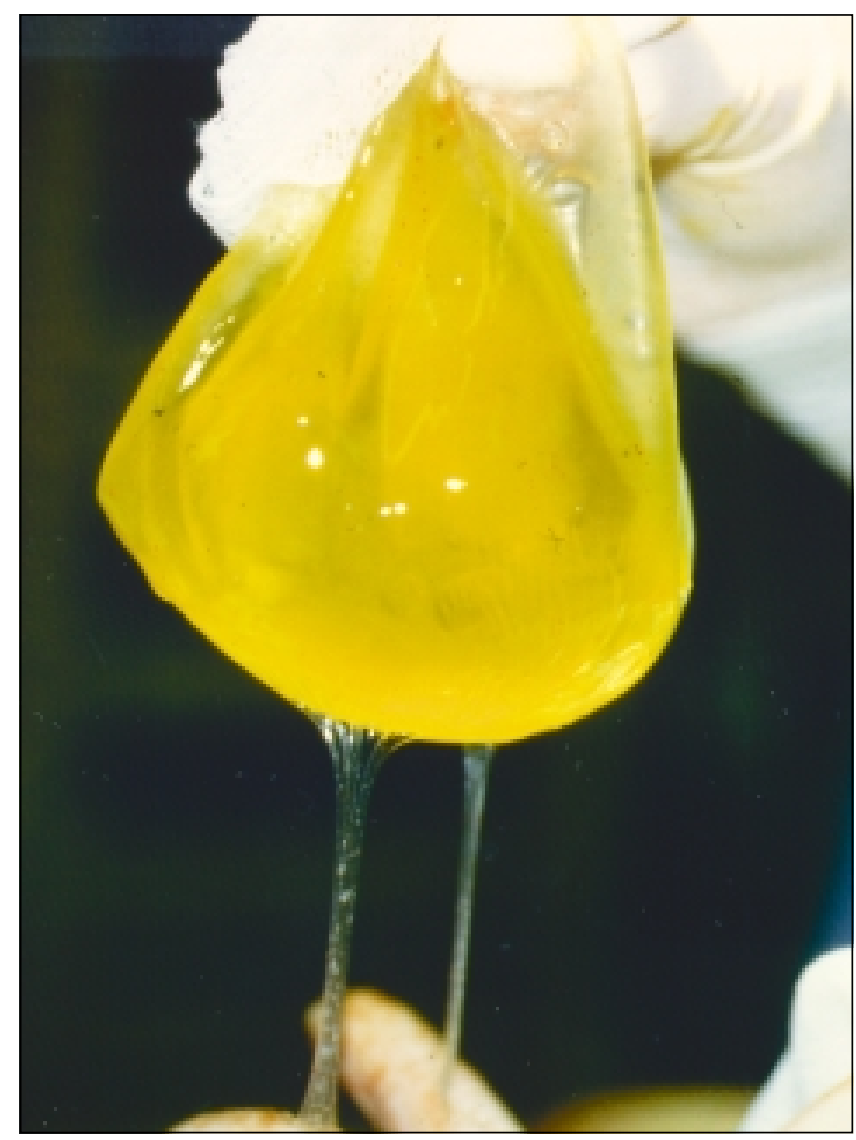

Figure 6) Second-generation gel implant that has leaked 12 years after implantation. There was a layer of stickiness on the implant and capsule surfaces. The silicone was seen to 'string out' over a variable distance. A 'pinhole' was seen in the shell when digital pressure was applied to the implant

meric shell, with gel detectable clinically on the surface of the implant and/or capsule (18-21). This may involve complete disruption of the shell (rupture), 'leaking' with a pinhole or tiny flaws in the shell. The resulting stickiness on the shell surface can sometimes 'string out' over a variable distance (Figure 6).

\section{Prevalence of disruption}

Earlier studies suggested that gel implants could fail over time $(22,23)$. However, before 1993, the incidence of disruption was thought to be very low. In their Breast Implant Resource Guide (1992) (24), the American Society of Plastic and Reconstructive Surgeons reported a spontaneous disruption incidence of $0.46 \%$ and an incidence of less than $1 \%$ following closed capsulotomy. In 1992, Angell (25) estimated an incidence of $4 \%$ to $6 \%$. In January 1992, the United States Food and Drug Administration Commissioner David Kessler (26) called for a voluntary moratorium on the use of gel breast implants. Following this, hundreds of thousands of women with gel implants rushed to have their implants removed. They perceived that there was a direct association between their implants and medical disease. Why else would they have been banned? 


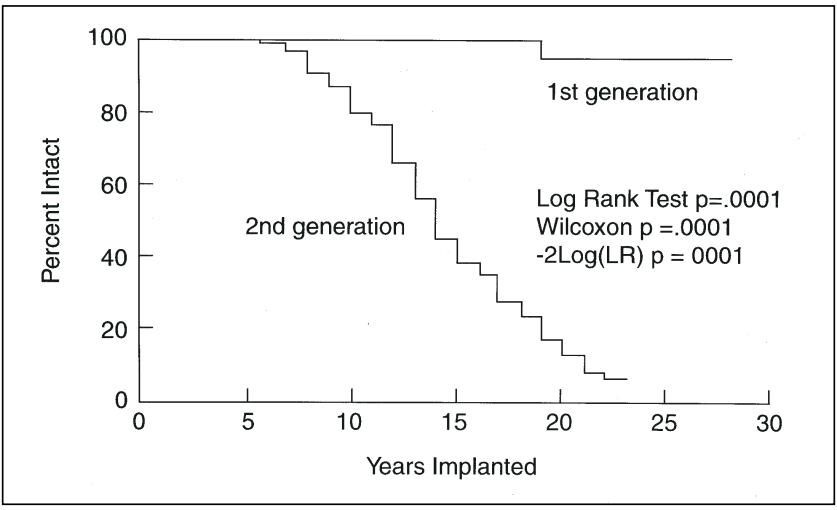

Figure 7) Kaplan-Meier survival curves for 28 first-generation implants and for 216 second-generation implants explanted from 1992 to 1998. LR Logrank

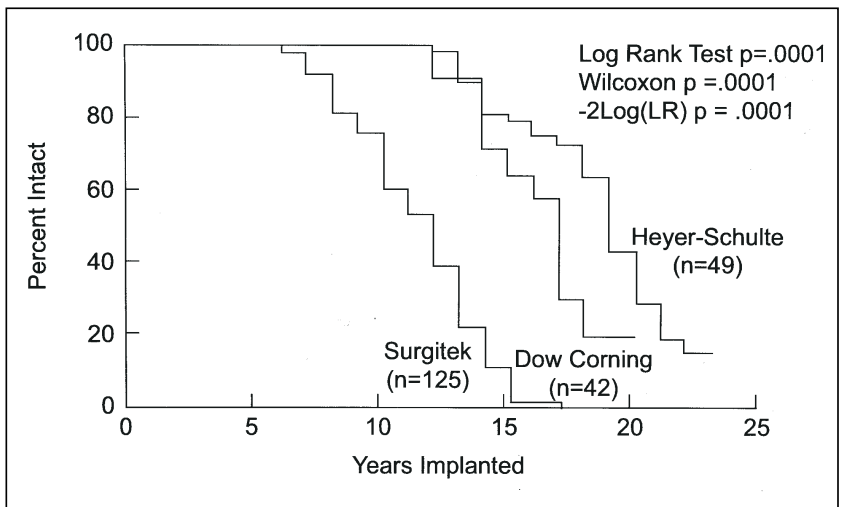

Figure 8) Kaplan-Meier survival curves for 216 second-generation gel implants comparing three different manufacturers. LR Logrank

Explantation became a common procedure for many surgeons. Soon, a surprising finding emerged - that many silicone gel implants had, in fact, become disrupted. In 1993, de Camara and colleagues (27) reported that, of 51 implants removed from 31 women, only 17 remained intact. All implants older than 10 years were leaking or ruptured. There were no first-generation implants in this study. In 1994, Peters and coworkers (28) reported a much larger series of patients with similar findings. There was a positive correlation between duration of implantation time and implant failure. Of the second-generation implants in place for longer than six years, $70 \%$ were disrupted. In 1995, Robinson and colleagues (20) reported 300 patients who had undergone explantation. Of 592 implants removed, $63.5 \%$ had disrupted.

Subsequently, Peters et al $(21,28,29)$ showed that the survival of gel implants was determined not only by their duration in situ, but also by their vintage (year of manufacture). Of 352 explanted implants analyzed, 20 were firstgeneration, and all were intact at explantation. By contrast, second-generation implants began to fail by leaking or rupturing after only four years in situ. By six years, $40 \%$ had failed. After 12 years, $95 \%$ had failed $(28,30)$. During the past few years, other groups have reported similar findings (31-34). These results have been reviewed in two publica-
TABLE 4

Status of 46 third-generation gel implants explanted from 1992 to 1998

\begin{tabular}{lccc}
\hline Manufacturer & Total & Intact & $\begin{array}{c}\text { Duration, mean years } \\
\text { (range) }\end{array}$ \\
\hline Dow Corning & 8 & 8 & $7.0(4-12)$ \\
McGhan & 14 & 14 & $6.7(5-11)$ \\
Surgitek & 18 & 15 & $5.3(3-10)$ \\
Cox Uphoff & 6 & 6 & $7.2(7-8)$ \\
\hline
\end{tabular}

tions $(34,35)$. Most of these studies have not addressed the generational issue of the explanted protheses.

\section{Current status of disruption}

It is now understood that there are both generation-specific and manufacturer-specific differences in the disruption properties of silicone gel breast implants (36). We have explanted 527 gel prostheses, mostly from women who were having symptoms. Of these, 28 were first-generation Dow Corning prostheses. They were explanted after 14 to 28 years in situ (mean 20.8 years). Only one of these implants was disrupted. All the others were clinically intact. Thus, in our studies, $96.4 \%$ of first-generation implants remained clinically intact after a mean of 20.8 years in situ. Not infrequently, firstgeneration implants can become disrupted during the explantation process $(9,36)$. This disruption usually occurs at the attachment site of the dacron patch, which is firmly embedded into the capsule. This is usually considered to be a mechanical disruption induced by the explantation procedure, rather than a failure of the implant per se $(9,36)$.

Several studies have shown that second-generation implants are much less durable than their first-generation counterparts $(9,18,20,28)$. From 1992 through 1998, we explanted 216 second-generation gel implants with identifiable manufacturers. At explantation, 73\% were disrupted. Figure 7 shows Kaplan-Meier survival curves for these 216 secondgeneration implants and for our 28 first-generation implants. These generational survival curves are vastly different.

Recent studies have demonstrated that the survival curves for second-generation implants are different for each manufacturer. Of the 216 implants, 125 were Surgitek, 49 were Heyer-Schulte and 42 were Dow Corning. A Kaplan-Meier survival curve for these 216 second-generation implants indicates that each of the manufacturers had a different survival curve (Figure 8). In this study, the overall differences among the manufacturers were assessed using the logrank test. Early differences were analyzed by using the Wilcoxon test, and the $-2 \log$ (longrank) test was used to analyze differences in later years. All three tests had a $\mathrm{P}<0.0001$. In this study, all 17 Surgitek implants that had been in place for 14 years or longer had ruptured. By contrast, second-generation implants made by Dow Corning and Heyer-Schulte were much more durable. For example, of 16 Dow Corning implants that were removed after 18 to 20 years in situ, 10 remained intact. Of 11 
Heyer-Schulte implants removed after 21 to 23 years in situ, five remained intact.

Studies have also shown that third-generation implants are much more durable than second-generation implants (18,20,21,28-30). From 1992 through 1998, we have explanted 46 third-generation gel implants with known manufacturers. Only three of these implants were disrupted. Again, there were manufacturer-specific differences (Table 4). Of the 46 implants, all eight Dow Corning Silastic II implants, which had been in place for four to 12 years (mean 7.0 years), were clinically intact. All 14 McGhan implants, which had been in place for five to 11 years (mean 6.7 years), were also clinically intact. All six Cox Uphoff implants, which had been in place for seven to eight years, were clinically intact. By contrast, of 18 Surgitek strong cohesive, low bleed implants in place from three to 10 years (mean 5.3 years), only 15 remained clinically intact at explantation (Table 4). Although third-generation implants are more durable than second-generation implants, their disruption frequencies have yet to be measured over the relevant periods of time.

\section{Selection bias}

It is important to recognize that there is an inherent selection bias in virtually all of the explantation-disruption studies that have been reported in the literature (18-21,27-35). Most women in these studies underwent surgery because they had problems related to their implants. It is conceivable that the prevalence of implant disruption in these patients could, therefore, be greater than those of 'control' or 'asymptomatic' patients who are not having problems related to their implants. The real denominator in these studies remains unknown.

\section{Mechanism of disruption}

Many theories have been advanced in an attempt to explain the mechanism of implant disruption. Recent extensive mechanical analyses comparing explanted with nonimplanted matched gel implants have indicated that - apart from the suspected localized areas of 'fold flaw' defects - the silicone elastomer shells of explants exhibit little or no large scale material degradation, even after implantation for as long as 28 years in situ $(37,38)$. A likely mechanism for disruption appears to be the 'fold flaw' theory, which was originally advanced by Worton and colleagues (39) in 1980 for salinefilled implants. These authors described a mechanism that did not develop until six to seven years after insertion. Then, implants developed a small hole at the end of one of the wrinkles in the elastomer shell. This was termed a 'fold flaw' leak and was thought to result from an 'internal abrasion' at a wrinkled (and presumably weakened) site in the shell. While this mechanism has not been scientifically proven, it seems logical.

The fold flaw mechanism would also apply to gel-filled implants because they had the same elastomeric shell composition as saline-filled implants. A fold flaw defect would be expected to be more common in an implant that was under- inflated, which would allow more folds to develop. Most second-generation gel implants were 'underinflated'. It would also be expected to be more common in saline implants than in gel implants because the more viscous nature of the gel would 'cushion' folds in the shell $(39,40)$. In 1996, Tebbetts (41) provided further support for the fold flaw theory. He showed that, in the body, all smooth-shelled, round saline implants fall to the bottom of the periprosthetic pocket, so that the upper pole of the implant is always collapsed and wrinkled, even if the implant is overfilled $15 \%$ past the manufacturer's recommended volume.

Many other mechanisms have also been suggested to explain implant disruption. Closed capsulotomy has been documented as a potential cause of implant rupture $(42,43)$, and some studies have shown an association between it and subsequent implant disruption (20). The pressures generated during closed capsulotomy have been shown to be $0.75 \mathrm{~kg} / \mathrm{cm}^{2}$ to $1.07 \mathrm{~kg} / \mathrm{cm}^{2}$ (10.6 to 15.2 pounds per square inch) (44). In 1975 to 1976, many implant manufacturers endorsed closed capsulotomy for the treatment of breast firmness. Subsequently, when ruptures were discovered among second-generation implants, they added a disclaimer to their product inserts. Other suggested mechanisms for disruption include trauma, general wear and tear, lipid infiltration of the elastomeric shell leading to weakening, mammography and manufacturing defects (42-48).

\section{Assessment of disruption}

Most often, implant disruption is diagnosed at explantation $(34,35)$. Occasionally, disruption can be diagnosed by mammography, but only if there has been extravasation of the gel into adjacent breast tissue. Then, a diagnosis is made when there is a large rent in the capsule or dispersion of the silicone globules throughout the breast (49). Ultrasound studies have not proved to be helpful to predict rupture (50). These tests are very operator dependent. In addition, if there is significant capsular contracture, then the resulting folds in the implant shell tend to give false positive results (50). The most accurate method to diagnose rupture is magnetic resonance imaging (MRI), using a specific breast coil. However, this technology is not indicated for monitoring patients with gel implants (3) because it is too costly and time consuming, and it has significant diagnostic limitations (particularly with first-generation and textured implants). Careful explantation and direct visual examination is the standard for diagnosing gel implant disruption (3).

\section{Consequences of implant disruption}

Most implant disruptions are probably 'silent' and are not associated with any particular symptoms or clinical findings $(28,30)$. Following most implant disruptions, the free silicone is usually contained within the capsule (intracapsular) $(30,49)$. However, in some patients, the free silicone can migrate into adjacent breast tissue. In our studies, extravasation was seen only with certain second-generation implants $(28,30)$. It was not seen with first- or third-generation implants. This may be related to the much thinner shell 
$(0.13 \mathrm{~mm})$ and the less cohesive nature of the gel of secondgeneration implants (Figure 3). Among second-generation implants removed from women requesting explantation from 1992 to 1995 , only $4.2 \%$ demonstrated extravasation at the time of their surgery $(28,30)$.

Several investigators have measured silicon levels in the capsules of women with intact and disrupted gel implants $(12,14-17)$. These studies have shown that the capsules of patients with disrupted implants did not have elevated levels of silicon compared with the capsules of patients with clinically intact implants. This is likely explained by the silicone bleed levels of intact implants.

Women with disrupted gel implants did not have differences in the frequency or titre of their autoantibodies compared with control patients without exposure to breast implants (51). Seventeen controlled epidemiological studies have demonstrated that there is not a significantly increased risk of connective tissue disease in women with silicone gel implants, whether they are intact or disrupted (52-54). Some studies have suggested that gel implants may be associated with a 'novel' or 'atypical' disease or syndrome (3). However, recent evidence has concluded that there does not appear to be even suggested evidence for the existence of a novel syndrome (3). Similarly, several studies have shown that there is not an increased prevalence of breast cancer among women with silicone gel breast implants (55-59). The evidence is conflicting on whether implants result in the discovery of breast cancer at later stages, but no studies have shown an increase in mortality because of diagnostic delays $(3,5)$.

Silicone from bleeding or from implant disruption may cause local inflammation in some women (60). Silicone gel has been found to migrate into both surrounding and distant tissues as a result of rupture or bleed. Reports have shown that silicone can be found in the breast, axillary lymph nodes, arms, fingers and groin (61-64). Capsular calcification of second-generation gel implants is more common in disrupted implants than in intact implants (9).

Several studies have shown that, although blood and serum silicon levels were higher in patients with gel implants than in controls, the levels were still within the range of control women without exposure to breast implants (65-68). Blood silicon levels among women with disrupted implants were not elevated above those of controls or those of women with intact implants $(65,67)$. Although earlier studies by Garrido and colleagues (61) indicated that silicone from ruptured gel implants could travel to a patient's blood and liver, subsequent nuclear magnetic resonance investigations in our laboratories under identical assay conditions failed to detect silicone in the blood of women with intact or ruptured implants (62). Semple and colleagues (63) have shown that the mean silicon levels in breast milk of 15 patients with gel implants was not significantly different from those of 30 control patients.

Several outcome studies have been conducted during the past few years (69-71). These have indicated that, following explantation of either intact or disrupted gel implants, many patients experience an improvement in their local symptoms (such as firmness and breast pain) and in their general psychological well being. However, in patients with fibromyalgia, inflammatory arthritis or autoimmune disease, there was no significant improvement in clinical or laboratory findings after explantation (69). These patients are being evaluated further in careful long term studies.

\section{MONITORING THE WOMAN WITH BREAST IMPLANTS}

Patients with breast implants need to be monitored at regular intervals for breast cancer detection. About $11 \%$ of all women will develop breast cancer in their lifetime. Most breast cancer $(75 \%)$ occurs in women over the age of 50 years. However, a significant component develops in younger women. Over $70 \%$ of women with breast cancer have no specific family history. There are three important modalities to detect breast cancer: breast self examination, clinical breast examination and mammography.

Women over the age of 30 years should undergo regular monthly breast self examination and annual clinical breast examination. These are optimally performed about one week after the menses, when cyclical ductal and alveolar growth, and water retention have settled (72). Breast self examination is important because $85 \%$ of breast lumps are first discovered by the patient. From age 50 years onwards, all women should also undergo annual screening mammography. Mammography is the single most important tool for the detection of small (less than $0.5 \mathrm{~cm}$ ) occult (nonpalpable) lesions, when the outcome is extremely favourable. From the age of 50 years onwards, annual screening mammography has been shown to result in a $30 \%$ to $40 \%$ reduction in overall breast cancer mortality (72).

In patients without breast implants, mammography usually involves two compression views: mediolateral oblique (MLO), where the breast is viewed from side to side, and craniocaudal (CC), where the breast is viewed from top to bottom (49). Breast implants have been shown to interfere with complete imaging of the breast (73-75). Hayes and colleagues (73) showed that when standard compression views were used, a breast implant obscured $22 \%$ to $83 \%$ of visualizable breast tissue. Gel (and saline-filled) implants interfere with imaging because they are not radiolucent (gel is worse than saline) (3). Additionally, both types of implants compress fat and glandular tissues, creating a more homogenous dense tissue that lacks the contrast needed to detect the subtle features of early breast cancer (3). To improve imaging, Eklund and Cardenosa (74) developed the implant displacement technique, whereby breast tissue is imaged after it is drawn anteriorly away from the implant. When this technique was used in women with breast implants and the results compared with preaugmentation films, the visualized area was still decreased, but only by $25 \%$ (76). It is important to understand that the imaging limitations associated with gel (and saline) implants are only partially overcome with these special views.

Mammography centres recommend an eight-view mam- 
mogram for patients with breast implants. Each breast undergoes the two standard compression views (MLO and CC). These views are then repeated using the implant displacement technique. Even with these imaging techniques, the visualized area of augmented breast can be significantly decreased, particularly if the implants are subglandular, large or associated with significant capsular contracture $(73,75,76)$. Under these conditions, there have been reports of patients whose breast cancer was missed after implant displacement mammography (75).

\section{EXPLANTATION}

Women with silicone gel breast implants frequently present to plastic surgeons to discuss explantation options regarding their implants. These patients are usually concerned about implant disruption and any potential complications that could develop from disruption. A woman may decide to undergo explantation for many reasons. If her breasts are firm or painful, she may perceive that her implants have disrupted. She needs to know that most implant disruptions are likely 'silent' and are not associated with any specific clinical findings. Her anxiety level may have increased because of media publicity. She may have developed certain symptoms that she thinks are related to her implants. Many patients still think that there is a causal relationship between gel implants and medical disease, 'or else why are the implant companies offering financial settlements?' A logical approach to explantation should involve consideration of the patient's personal anxiety and concerns, her implant vintage, her current clinical status and whether she chooses to replace her implants or undergo mastopexy.

\section{Indications for explantation}

There are a number of relative indications for explantation of silicone gel implants. These may include implant disruption, excessive breast firmness and/or pain, and patient anxiety. Explantation may be indicated if a patient's implants are known to have disrupted (76). Although the release of gel into tissues is not known to cause medical disease, it may result in local complications $(3,76)$. An intracapsular rupture may become extracapsular. Explantation may be indicated if a woman has a poor clinical result, with excessive breast firmness and/or pain. Explantation is particularly indicated in this type of patient if she has a second-generation implant, which is more likely disrupted. Many women with significant local breast symptoms (firmness and pain) have demonstrated a marked improvement in their symptoms after explantation (30). Other women (and their families) may have become so anxious about 'potential health problems related to their implants' that they demand explantation.

\section{Explantation considerations}

Implant vintage: Any woman considering explantation needs to be fully informed about many issues related to her implants and breast status. Current knowledge indicates that the vast majority of first- and third-generation implants are presently intact. Therefore, if her primary concern is implant disruption, then that is likely not an issue with these particular implants. By contrast, many second-generation implants have disrupted. This finding is manufacturer-dependent. Dow Corning and Heyer-Schulte implants are much more likely to be intact after 18 to 20 years than Surgitek implants. Patients need to know that ultrasound studies are not helpful to predict rupture and that mammography is helpful only for the few patients who have extravasation. MRI studies are not currently indicated to monitor implant status.

Capsulectomy: There is no overall consensus regarding the role of capsulectomy in women with second- and thirdgeneration gel implants (77). Most surgeons routinely perform a capsulectomy when capsules are calcified. Many surgeons also perform a capsulectomy if capsules are very thickened. Some surgeons recommend capsulectomy if implants are disrupted (77) in order to remove any silicone that could be present in the capsules. By contrast, many surgeons prefer to leave capsules in situ if they are thin, particularly if the implants are submuscular, when removal from the ribcage could lead to increased morbidity (70).

If a capsulectomy is performed, particularly if there is extensive capsular calcification or thickening, then the patient may be left with a greater deformity than if they are left in situ. Certain patients remain convinced that all capsular tissue needs to be fully removed at explantation. These patients need to understand the morbidity and deformity that can result from this procedure, particularly if the breast tissue is very thin, or if the implants are subsmuscular with large pockets.

First-generation implants: If a woman has first-generation implants, then her capsules will be heavily calcified (9). If she undergoes explantation, she will require capsulectomy, or else her calcified capsules will persist as a mass that can interfere with subsequent clinical breast examination and mammography (49). If a capsulectomy is done, there is usually a significant deformity, particularly if she chooses not to undergo replacement of her implants. Figure 9 (top) shows a 48-year-old woman with class IV capsular contractures, presenting 28 years after she received bilateral subglandular gel implants. She presented with excessive pain and firmness, which had prevented her from sleeping prone for many years. No one had been able to touch her breasts for about 10 years. She did not want her implants replaced. One year after explantation and total removal of her extensively calcified capsules, she presented with considerable deformity (Figure 9, bottom). However, she was pleased because her local symptoms had disappeared. She was 'a new woman'. Her cosmetic result may have been better with implant replacement.

If a woman with first-generation implants undergoes saline implant replacement after explantation and capsulectomy, then she usually obtains a better cosmetic result than if she foregoes implant replacement. Figure 10 (top) shows a 54-year-old woman with first-generation gel implants and class IV contractures. She obtained an acceptable cosmetic result one year after explantation, total removal of her calcified capsules and replacement of her gel implants with saline 

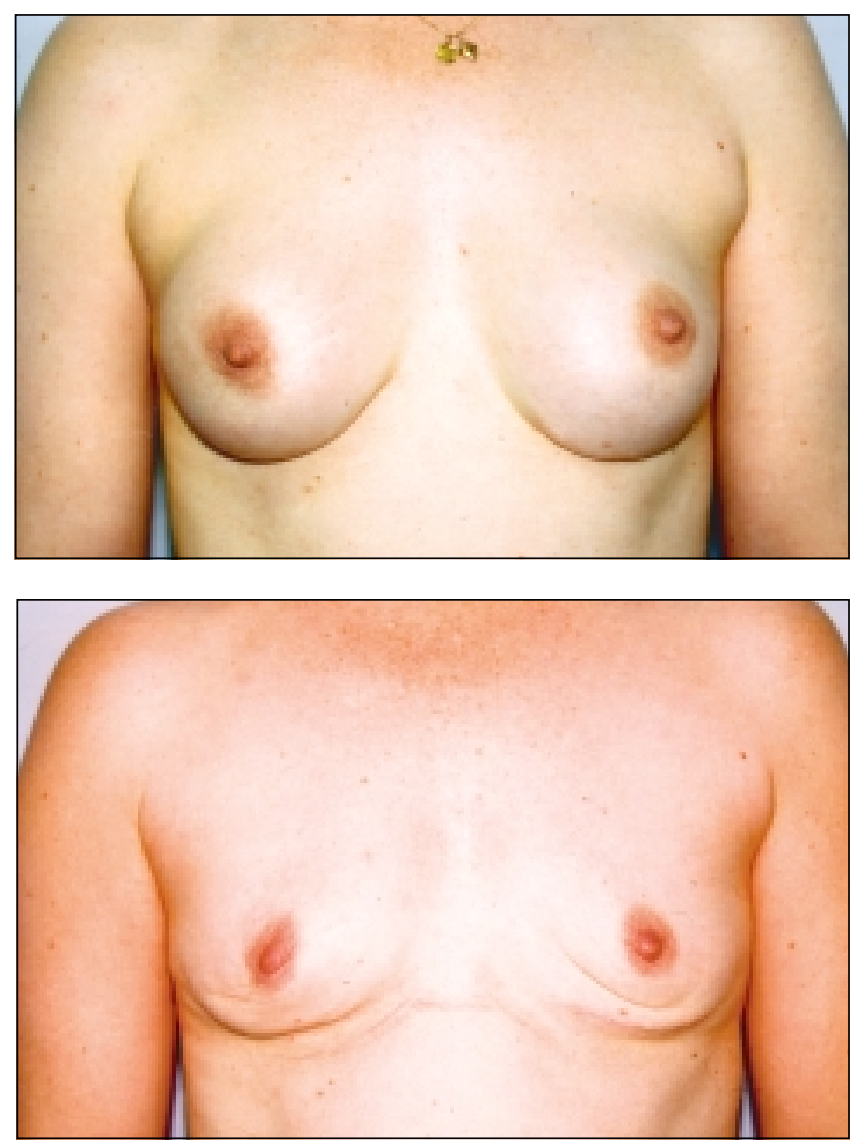

Figure 9) Top A 48-year-old woman with class IV capsular contractures 28 years after receiving subglandular gel implants. Bottom Result one year after explantation and total capsulectomy for calcified capsules

implants (Figure 10, bottom). However, patients such as this need to be carefully warned that there may be visible and palpable folds in their breasts, because of the watery nature of the saline compared with the viscous nature of the gel in their previous implants. These folds can be reduced (but not eliminated) by overfilling the implants. Submuscular insertion of implants can theoretically reduce these folds. However, patients with first-generation implants usually have major contractures with stretching of their central breast tissue. Then, if implants are inserted under the muscle, the central breast tissue would appear 'loose and empty' over the breast mound. In addition, with long-standing capsular contracture, there can be fibrosis and contracture of the pectoralis muscle itself, which restricts submuscular insertion of implants. The patient in Figure 10 had these findings; therefore, her new implants had to be placed in the subglandular plane.

Second- and third-generation implants: Patients with second- or third-generation implants can expect variable results following explantation. Their results are dependent on the original implant size and location, the degree and duration of capsular contracture, whether a capsulectomy is performed and whether they choose to replace their implants or undergo a mastopexy. If their gel implants are replaced with saline implants, then the cosmetic result is usually better than if no
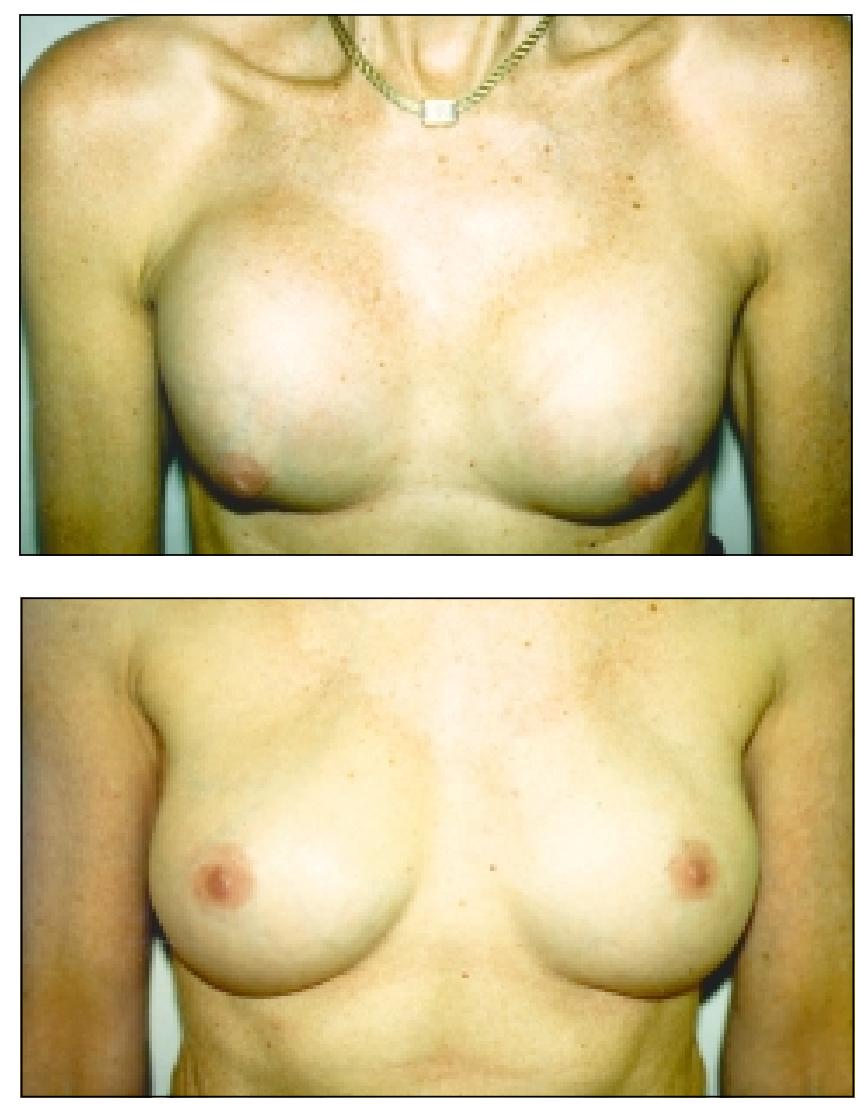

Figure 10) Top A 54-year-old woman with first-generation gel implants and class IV capsular contractures. Bottom Result one year after explantation, total removal of calcified capsules and saline implant replacement. Her breasts are soft (class I) and pain-free. This patient's pectoralis muscle was thin and scarred, which prevented submuscular insertion of her replacement implants

further implants are inserted. In our studies, only about half of our explantation patients elect to replace their implants with saline implants. Other patients feel that their breast priorities have become altered over time, and they no longer want breast implants.

Patients with small or moderate-sized subglandular or submuscular gel implants often obtain a satisfactory result even if they choose not to replace their implants. Figure 11 (top) shows a 42-year-old woman with class IV contractures, presenting seven years after the subglandular insertion of $200 \mathrm{~cm}^{3}$ gel implants. One year after explantation and total capsulectomy, she had an acceptable result, even without implant replacement (Figure 11, bottom). Figure 12 (top) shows a 35-year-old woman with a class I result, seven years after the submuscular insertion of $220 \mathrm{~cm}^{3}$ gel implants. One year after explantation and capsulectomy (at the patient's request), she had an acceptable cosmetic result (Figure 12, bottom).

Surgeons should always consider that if implants are inserted in the subglandular plane, then a significant amount of the breast is compromised during mammographic imaging. This factor may be important in the older patient, whereas it may have been less important when a woman was younger. Figure 13 (top) shows a 39-year-old woman with class IV 

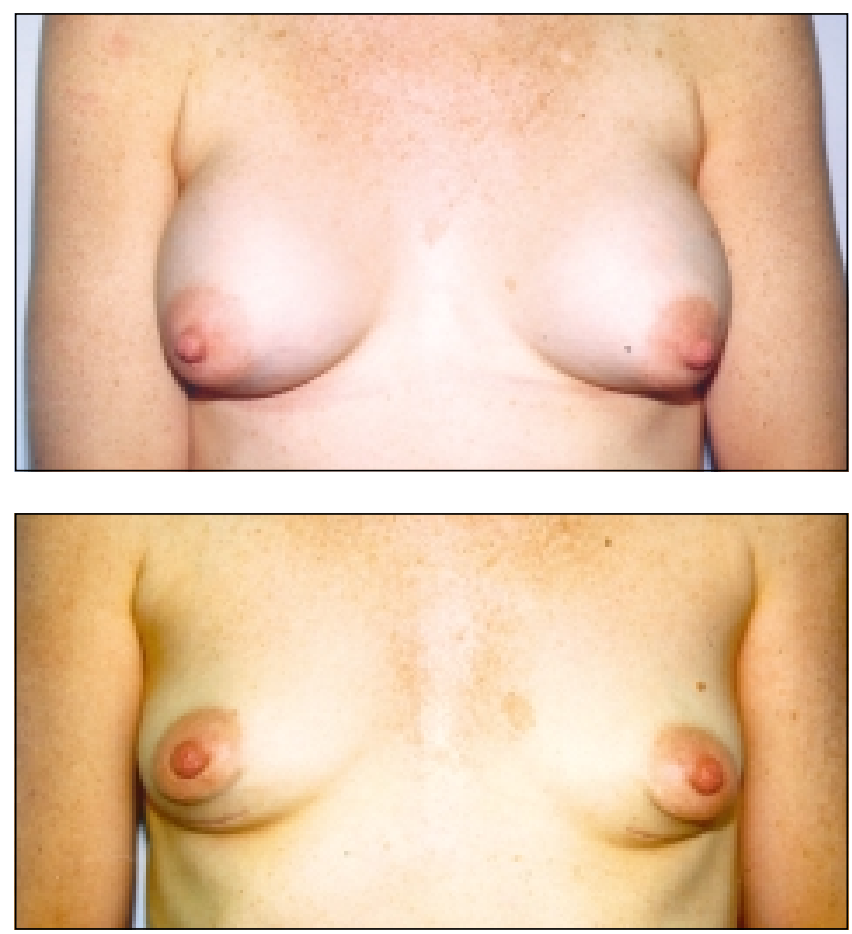

Figure 11) Top A 42-year-old woman with bilateral class IV capsular contractures six years after bilateral $180 \mathrm{~cm}^{3}$ subglandular implants. Bottom Appearance one year after explantation and total capsulectomy, with no implant replacement
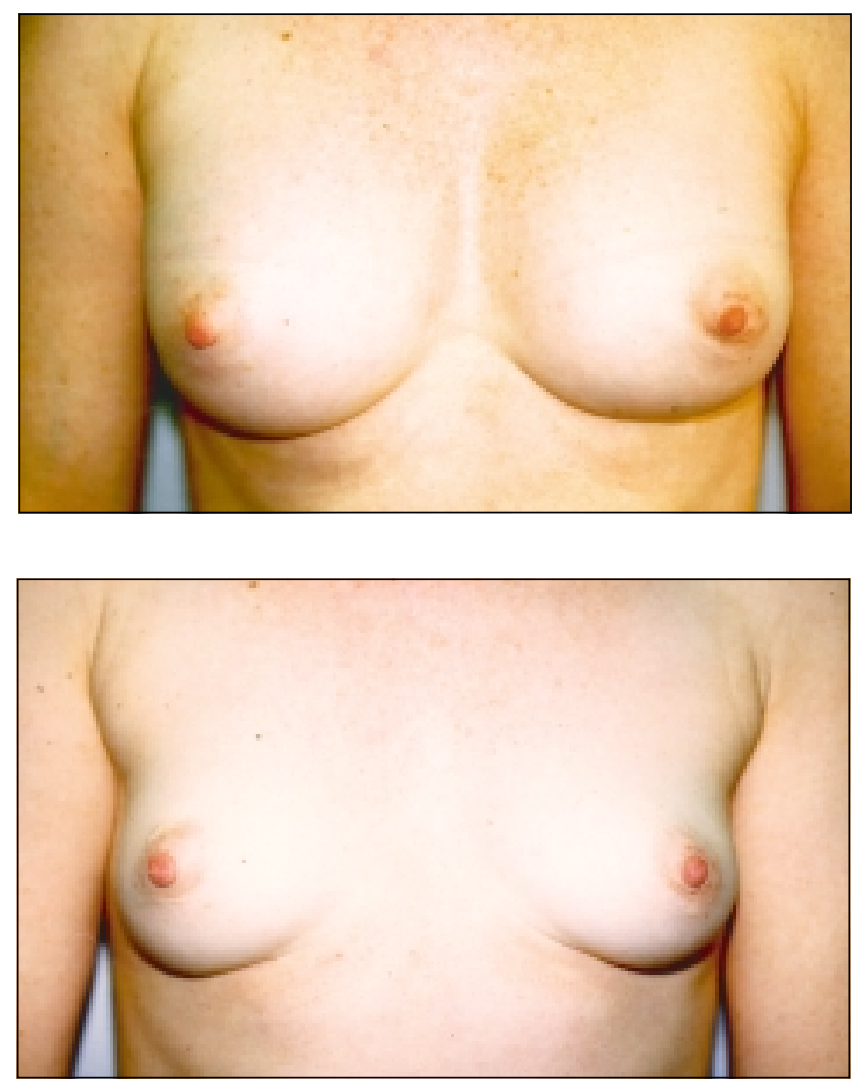

Figure 12) Top $A$ 35-year-old woman with a class I result seven years after the submuscular insertion of $220 \mathrm{~cm}^{3}$ gel implants. Bottom One year after explantation and capsulectomy (at the patient's request), she had an acceptable cosmetic result without implant replacement
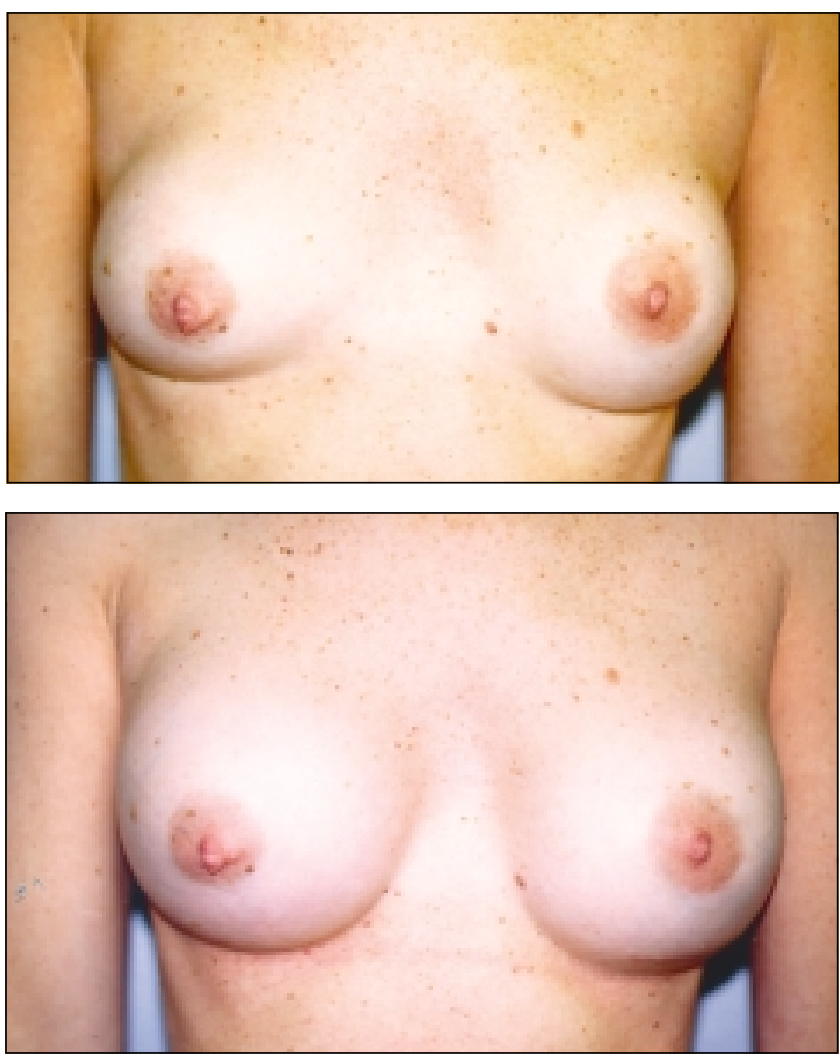

Figure 13) Top A 39-year-old woman with Baker class IV capsular contractures 14 years after the insertion of subglandular $190 \mathrm{~cm}^{3}$ secondgeneration gel implants. Bottom Acceptable result one year after explantation of ruptured implants, total removal of calcified capsules and insertion of $330 \mathrm{~cm}^{3}$ submuscular saline implants

capsular contractures 20 years after the subglandular insertion of $190 \mathrm{~cm}^{3}$ gel implants. One year later, she had an acceptable result (class I) after explantation of her ruptured implants, total capsulectomy (because of calcified capsules) and insertion of submuscular $330 \mathrm{~cm}^{3}$ saline implants (Figure 13, bottom). The best results from a submuscular conversion are obtained if the original implants were small, the central breast tissue is not excessively stretched and larger replacement implants are inserted so that the central breast tissue becomes filled out (Figure 13).

Patients with large gel implants, particularly if they have been inserted in the subglandular plane, will have a major cosmetic deformity if their implants are not replaced or if they elect to forego further reconstructive surgery. Figure 14 (bottom) shows a poor cosmetic result in a 29-year-old woman one year after the explantation (without capsulectomy) of $560 \mathrm{~cm}^{3}$ gel implants, which had been inserted seven years earlier. This patient may have had a better cosmetic result if she had chosen implant replacement and/or mastopexy.

The issue of safety among the estimated 1.5 million women with gel-filled breast implants has become more than 'a woman's issue'. It is one that affects partners, families, taxpayers and society. Very few surgical procedures are associated with the high incidence of potential local complica- 

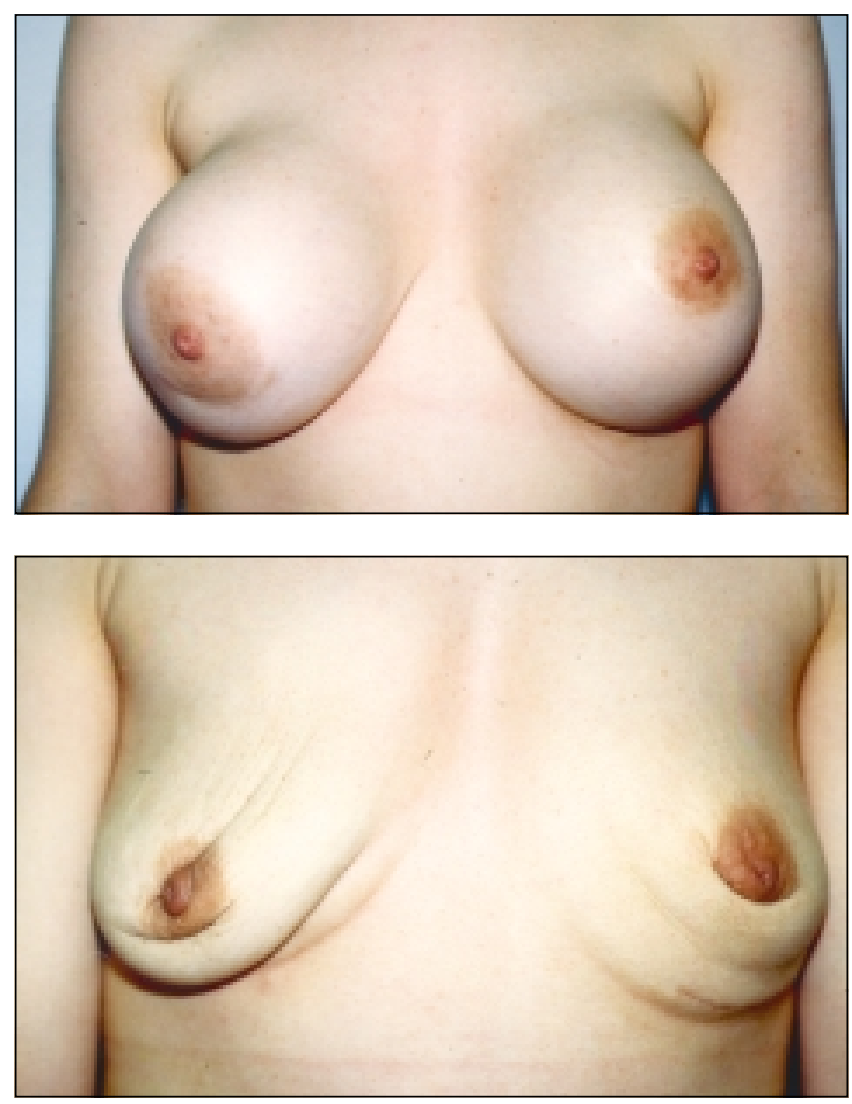

Figure 14) Top Class IV capsular contractures in a 29-year-old woman seven years after subglandular insertion of $560 \mathrm{~cm}^{3}$ gel implants. Bottom Result one year after explantation without capsulectomy. This patient may have had a better cosmetic result if she had chosen implant replacement or mastopexy

tions that are inherent after the insertion of gel implants. In many cases, women have indicated that they were not informed of known complications before receiving their implants. Currently, every woman contemplating explantation of her gel implants must be fully informed about her implant status and the possible treatment options.

ACKNOWLEDGEMENTS: This research was funded by grants from the Medical Research Council of Canada, Health Canada, the Educational Foundation of the American Society of Plastic and Reconstructive Surgeons, The Canadian Society of Plastic Surgeons, and by unrestricted funding from Dow Corning Corporation

\section{REFERENCES}

1. Cronin TD, Gerow FG. Augmentation mammaplasty; a new natural feel prosthesis. Transactions of the Third International Congress of Plastic Surgery. Amsterdam: Excerpta Medica Foundation, 1964:41-9.

2. Callahan T. Tensile strength and liquid silicone bleed. Presented at the United States Food and Drug Administration General Plastic Surgery Devices Panel Meeting, Bethesda, February 21-28,1992;1:73-84.

3. Submission of Rule 706 National Science Panel Report. Silicone Gel Breast Implant Products Litigation (MDL 926), Master File No CV 92-P-10000-S, United States District Court, Alabama, 1998.

4. Cook RR, Delongchamp RR, Woodbury MA, et al. The prevalence of women with breast implants in the United States - 1989. J Clin Epidemiol 1995;48:529-6.
5. Silicone Gel Breast Implants. The Report of the Independent Review Group. Cambridge: Rogers Associates, 1998.

6. Middleton MS. Mammary Implant Product List 1962-1968. San Diego: UCSD Magnetic Resonance Institute, 1999.

7. Middleton MS. Magnetic resonance evaluation of breast implants and soft-tissue silicone. Top Magn Reson Imaging 1998;9:92-137.

8. Peters WJ, Smith DC. Calcification of breast implant capsules: Incidence, diagnosis and contributing factors. Ann Plast Surg 1995;34:8-11.

9. Peters WJ, Pritzker KP, Smith DC, et al. Capsular calcification associated with silicone breast implants: incidence, determinants, and characterization. Ann Plast Surg 1998;41:348-60.

10. Eisenstein Zukin H, Silberfeld RM, Hargrove S. Breast Implant Litigation: Proper Defendants/Who to Name: Implant Manufacturers, Implant Distributors, Gel Suppliers. Dow Corning Corporation Document 080102057-080102065. Los Angeles: Simke, Chodos, Silberfeld and Anteau, Inc.

11. Barker DE, Retsky MI, Schultz S. "Bleeding” of silicone from bag-gel breast implants and its clinical relation to fibrous capsule reaction. Plast Reconstr Surg 1978;61:836-41.

12. Peters W, Smith D, Lugowski S, McHugh A, Keresteci A, Baines C. Analysis of silicon levels in capsules of gel and saline breast implants and of penile prostheses. Ann Plast Surg 1995;34:578-84.

13. Yu LT, Latorre G, Marotta J, Batich C, Hardt NS. In vitro measurement of silicone bleed from breast implants. Plast Reconstr Surg 1996;97:756-64.

14. Peters WJ, Smith D, Lugowski S. Silicon capsule assays with low bleed silicone gel breast implants. Plast Reconstr Surg 1996;97:1311-2.

15. Peters WJ, Smith DC, Lugowski S. Silicon levels in patients with silicone implants. Ann Plast Surg 1995;35:441-3.

16. Evans GRD, Baldwin BJ. From cadavers to implant: silicon tissue assays of medical devices. Plast Reconstr Surg 1997;100:1459-65.

17. Schnur PL, Weinzweig J, Harris JB, et al. Silicon analysis of breast and periprosthetic capsular tissue from patients with saline or silicone gel breast implants. Plast Reconstr Surg 1996;98:798-803.

18. Peters W, Keystone E, Smith D. Factors affecting the rupture of silicone-gel breast implants. Ann Plast Surg 1994;32:449-51.

19. Peters WJ. Current status of silicone gel breast implants. Can J Plast Surg 1994;2:18-25.

20. Robinson OG, Bradley EL, Wilson DS. Analysis of explanted silicone implants: A report of 300 patients. Ann Plast Surg 1995;34:1-7.

21. Peters WJ. The rupture of silicone-gel breast implants. Ann Plast Surg 1994;33:462-3.

22. Peters WJ. The mechanical properties of breast prostheses. Ann Plast Surg 1981;6:179-81.

23. Van Rappard JHA, Sonneveld GJ, Van Twisk R, et al. Pressure resistance of breast implants as a function of implantation time. Ann Plast Surg 1988;21:566-9.

24. Breast Implant Resource Guide. Arlington Heights: American Society of Plastic and Reconstructive Surgeons, 1992.

25. Angell M. Breast implants: Protection or paternalism? N Engl J Med 1992:326:1695-6.

26. Kessler DA. The basis of the FDA's decision on breast implants. N Engl J Med 1992;326:1713-5.

27. de Camara DL, Sheridan JM, Kammer BA. Rupture and aging of silicone gel breast implants. Plast Reconstr Surg 1993;91:828-34.

28. Peters W, Smith D, Lugowski S. Failure properties of 352 explanted silicone-gel breast implants. Can J Plast Surg 1996;4:55-8.

29. Peters WJ. Rupture of silicone-gel breast implants. Lancet 1998;3541:521-2.

30. Peters W, Smith D, Fornasier V, et al. An outcome analysis of 100 women after explantation of silicone gel breast implants. Ann Plast Surg 1997;39:8-19.

31. Beekman WH, Feitz R, Hage JJ, Mulder JW. Life span of silicone gel-filled mammary prostheses. Plast Reconstr Surg 1997;100:1723-6.

32. Cohen BE, Biggs T, Cronin ED, Collins DR Jr. Assessment and 
longevity of the silicone gel breast implant. Plast Reconstr Surg 1997;99:1597-1601.

33. Rohrich RJ, Adams WP, Beran SJ, et al. An analysis of silicone gel-filled breast implants: Diagnosis and failure rates. Plast Reconstr Surg 1998;102:2304-8.

34. Goldberg EP, Widenhouse C, Marotta J, Martin P. Failure of silicone gel breast implants: Analysis of literature data for 1652 explanted prostheses. Plast Reconstr Surg 1997;100:281-4.

35. Young VL, Peters W, Brandon HJ, Jerina KL, Wolf CJ. Determining the frequency of breast implant failure requires sound scientific principles. Plast Reconstr Surg 1998;102:1295-1301.

36. Peters W, Smith D, Lugowski S. All silicone gel breast implants were not created equal. Ann Plast Surg 1999;43:97-9.

37. Brandon HJ, Young VL, Wolf CJ, et al. Variability in the properties of silicone gel breast implants. Proceedings of the 24th Annual Meeting of the Society of Biomaterials, San Diego, April 22-26, 1998:400-1.

38. Brandon HJ, Peters WJ, Young VL, et al. Analysis of two Dow Corning breast implants removed after 28 years of implantation. Aesth Surg J 1999;19:40-8

39. Worton EW, Seifert LN, Sherwood R. Late leakage of inflatable silicone breast prostheses. Plast Reconstr Surg 1980;65:302-6.

40. McGrath MH, Burkhardt BR. The safety and efficacy of breast implants for augmentation mammoplasty. Plast Reconstr Surg 1984;74:550-60.

41. Tebbetts JB. What is adequate fill? Implications in breast implant surgery. Plast Reconstr Surg 1996;97:1451-4.

42. Nelson GD. Complications from the treatment of fibrous capsular contracture of the breast. Plast Reconstr Surg 1980;66:969-70.

43. Eisenberg HV, Barrels JJ. Rupture of silicone bag gel breast implant by closed compressive capsulotomy. Plast Reconstr Surg 1979;59:849-50.

44. Gruber RP, Friedman G. The pressures generated by closed capsulotomies of augmented breasts. Plast Reconstr Surg 1978;62:379-80.

45. Baines CJ, Arseneau J, Smith DC. Summary of the report on silicone-gel filled breast implants. CMAJ 1992;147:141-6.

46. Adams WP, Robinson JB, Rohrich RJ. Lipid infiltration as a possible biologic cause of silicone gel breast implant aging. Plast Reconstr Surg 1998; 100:65-8

47. Peters W, Smith DC. Lipid infiltration as a possible biologic cause of silicone gel breast implant aging, invited discussion. Plast Reconstr Surg 1998;101:69-7.

48. Pickford MA, Webster MH. Implant rupture by mammography. Br J Plast Surg 1994;47:512-4

49. Peters WJ, Smith DC, Grosman H, Fornasier V. The role of mammography to assess complications of silicone-gel breast implants. Can J Plast Surg 1995;3:1-6.

50. Medot M, Landis GH, McGregor CE, et al. Effects of capsular contracture on ultrasonic screening for silicone gel breast implant rupture. Ann Plast Surg 1997;39:337-41.

51. Peters W, Keystone E, Snow K, Rubin L, Smith D. Is there a relationship between autoantibodies and silicone-gel implants? Ann Plast Surg 1994;32:1-7.

52. Gabriel SE, O'Fallon WM, Kurland LT, Beard CM, Woods JE, Melton LJ III. Risk of connective-tissue diseases in female health professionals. A retrospective cohort study. N Engl J Med 1994;330:1697-702.

53. Sanchez-Guerrero J, Colditz GA, Karlson EW, Hunter DJ, Speizer FE, Liang MH. Silicone breast implants and the risk of connective-tissue diseases and symptoms. N Engl J Med 1995;332:1666-70.

54. Perkins LL, Clark BD, Klein PJ, Cook RR. A meta-analysis of breast implants and connective tissue disease. Ann Plast Surg $1995 \cdot 35 \cdot 561-70$
55. Brinton LA, Brown SL. Breast implants and cancer. J Natl Cancer Inst 1997;89:1341-9.

56. Deapen DM, Berstein L, Brody GS. Are breast implants anticarcinogenic? A 14-year follow-up of the Los Angeles Study. Plast Reconstr Surg 1997;99:1346-53.

57. Birdsell DC, Jenkins $H$, Berkel H. Breast cancer diagnosis and survival in women with and without breast implants. Plast Reconstr Surg 1993;92:795-800.

58. Berkel H, Birdsell DC, Jenkins H. Breast augmentation: a risk factor for breast cancer? N Engl J Med 1992;326:1649-53.

59. Deapen DM, Brody GS. Augmentation mammoplasty and breast cancer: A 5-year update of the Los Angeles study. Plast Reconstr Surg 1992;89:660-5.

60. Thomsen JL, Christensen L, Nielsen M, et al. Histologic changes and silicone concentration in human breast tissue surrounding silicone breast prostheses. Plast Reconstr Surg 1990;85:38-41.

61. Garrido L, Pfleiderer B, Jenkins BG, Hulka CA, Kopans DB. Migration and chemical modification of silicone in women with breast prostheses. Magn Reson Med 1994;31:328-30.

62. Macdonald P, Plavac N, Peters W, Lugowski S, Smith D. Failure of 29Si to detect increased blood silicon levels in silicone gel breast implant recipients. Anal Chem 1995;67:3799-801.

63. Semple JL, Lugowski SJ, Baines CJ, Smith DC, McHugh A. Breast milk contamination and silicone implants: preliminary results using silicon as a proxy measurement for silicone. Plast Reconstr Surg 1998;102:528-33.

64. Kulbert DA, Mackenzie D, Steiner JH, et al. Monitoring the axilla in patients with silicone gel implants. Ann Plast Surg 1995;35:580-4.

65. Peters WJ, Smith DC, Lugowski S, et al. Silicon and silicone levels in patients with silicone implants. In: Potter M, Rose N. Current Topics in Microbiology and Immunology. New York: Springer-Verlag, 1996:39-48.

66. Peters W. Silicon assays in women with and without silicone gel breast Implants - a review. Ann Plast Surg 1999;43:324-332.

67. Peters WJ, Smith D, Lugowski S. Do patients with silicone-gel breast implants have elevated levels of blood silicon compared with control patients? Ann Plast Surg 1995;43:343-7.

68. Leung FY, Edmond P. Determination of silicon in serum and tissue by electrothermal atomic absorption spectrometry. Clin Biochem 1997;33:399-403.

69. Peters WJ, Smith DC. Outcome analysis of women after explantation of silicone gel breast implants. Ann Plast Surg 1998;41:102-3.

70. Slavin SA, Goldwyn RM. Silicone gel implant explantation: reasons, results, and admonitions. Plast Reconstr Surg 1995;95:63-9.

71. Svahn JK, Vastine VL, Landon BN, Dobke MK. Outcome of mammary prostheses explantation: a patient perspective. Ann Plast Surg 1996;36:594-600.

72. Miller AB, Baines CJ, To T, Wall C. Canadian national breast screening study: 2 . Breast cancer detection and death rates among women aged 50 to 59 years. CMAJ 1992;147:1477-594.

73. Hayes H Jr, Vandergrift J, Diner WC. Mammography and breast implants. Plast Reconstr Surg 1988;82:1-6.

74. Eklund GW, Cardenosa G. The art of mammographic positioning. Radiol Clin North Am 1992;30:21-53.

75. Peters W, Fornasier V. Missed breast cancer in two patients with prepectoral silicone gel breast implants following implant displacement mammography. Can J Plast Surg 1997;5:127-9.

76. Silverstein MF, Handel N, Gamagani P, et al. Breast cancer in women after augmentation mammoplasty. Arch Surg 1988;123:681-5.

77. Young VL. Guidelines and indications for breast implant capsulectomy. Plast Reconstr Surg 1998;102:884-91. 